\title{
EFFECT OF THERMAL AGEING ON THE OIL-PAPER INSULATION
}

\author{
Lukáš LISOŇ, Iraida KOLCUNOVÁ, Miroslav KMEC \\ Department of Electric Power Engineering, Faculty of Electrical Engineering and Informatics, Technical University of Košice, \\ Letná 9, 04200 Košice, Slovak Republic,e-mail: lukas.lisoň@tuke.sk, iraida.kolcunova@tuke.sk, miroslav.kmec@tuke.sk
}

\begin{abstract}
Insulation system is one of the most important part of electrical devices. This insulation system is usually composed by solid part and liquid part. Oil impregnated insulation paper is used in transformers for many years. There are a lot of factors which have significant influence on the insulation system during the life time of electrical devices. Temperature is one of the factors which has strong influence on condition of oil paper insulation. This paper is focused on measuring of electrophysical properties of oil paper as relative permittivity, AC breakdown voltage and polarization index of insulation before and after thermal ageing. Vegetable oil paper insulation and mineral oil paper insulation were investigated and analyzed.
\end{abstract}

Keywords: oil-paper, properties, ageing, breakdown voltage, relative permittivity

\section{INTRODUCTION}

In a liquid-filled transformer, the insulating liquid plays an important function by providing both the electrical insulation (in combination with a solid such as cellulose) and the means of transferring the thermal losses to the cooling system. The insulating liquid can also provide important and easily obtainable information for use in diagnosing the health of a transformer [1]. For the reliable operation of high voltage power transformers, it is essential that the cellulose insulation structures used in their construction are completely oil impregnated. The oil impregnation procedure is important to ensure that no cavities are left inside the cellulose insulation and thereby dangerous partial discharges are avoided [2]. The thermal degradation affects electrical, chemical and mechanical properties of insulation paper. Thermal stress is one of key factors which cause the degradation of oil-paper insulation. Accelerate thermal experiments have been performed by many researchers over the last a few decades, and the results of these experiments have been used to make predictions of transformer lifetime [3]. Conventional mineral oil is some possibility of environmental pollution and fire with explosion. But natural ester insulating oils are non-toxic, more biodegradable and less flammable than a mineral oil. Therefore conventional mineral oil is being replaced with natural ester insulating oil [4]. Influences of thermal ageing on the natural ester impregnated paper and mineral oil impregnated paper were researched.

\section{EXPERIMENT}

Influence of thermal ageing on rapeseed oil impregnated paper and mineral oil (ITO 100) impregnated paper was tested. Measurement of base electrophysical properties, as relative permittivity, breakdown voltage and polarization index were realized. For these purposes was chosen insulation paper with $0.06 \mathrm{~mm}$ thickness. Insulation system of transformers is composed with several layers of insulation paper and oil, therefore our experiment is composed of six layers of insulation paper and oil. The thickness of paper insulation was $0.36 \mathrm{~mm}$. The temperature of accelerated ageing was $90^{\circ} \mathrm{C}$. We gave a piece of copper into samples of oil paper, for simulating a real insulation system of transformer. This experiment was made at room temperature and atmospheric pressure. The first measurement was realized at 0 hours thermal ageing, and next two different thermal aging intervals have been selected (500 hours and 750 hours).

\section{METHODS OF MEASUREMENT}

The measurement methods which were used for these experiments are described in following chapters.

\subsection{AC breakdown voltage of oil impregnated paper}

Electrical breakdown voltage is one of the most important properties of the dielectric material. The $\mathrm{AC}$ breakdown voltage was measured using two electrodes which were $25 \mathrm{~mm}$ diameter brass hemispherical types. Breakdown voltage of mineral oil paper insulation and rapeseed oil paper insulation were measured with HighVoltage DTS-60D equipment (Fig. 1). For each types oil, five oil impregnated paper samples were tested, and the average value was calculated. The voltage was applied at a rise rate of $2 \mathrm{kV} . \mathrm{s}^{-1}$ until breakdown occurs. Paper insulation was changed after the each breakdown. There was a 1 minute break between two measurements.

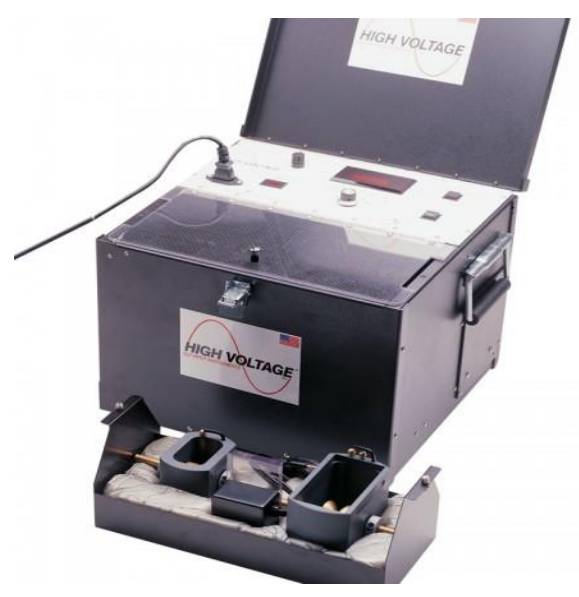

Fig. 1 High Voltage DTS-60D 


\subsection{Relative permitivity}

Relative permittivity $\varepsilon_{\mathrm{r}}$ it can defined as ratio of capacity dielectric between capacitor electrodes and capacity of the same capacitor which is filled by air. It describes how many times force is exerted on charge in dielectric lower than in vacuum. Relative permittivity is used to expresses of skills of material accumulate electric charge. Accumulation of electric charge is consequence of polarization of material [5]. Polarization is moving of a free charges in electric field. It depend of temperature of specimens and frequency of voltage. Relative permittivity is dependent on dipole moments of molecules, and their speed in electrical field [6]. Relative permittivity in depending on voltage were measured with automatic Schering bridge TETTEX AG (Fig. 2). Measurement was realized at temperature $20^{\circ} \mathrm{C}$ and voltage was increased from $0.2 \mathrm{kV}$ to $2 \mathrm{kV}$ with step $0.2 \mathrm{kV}$ at frequency $50 \mathrm{~Hz}$. The electrode system for measurement of relative permittivity is shown on (Fig. 4). In chapter of results and discussion, the rapeseed oil paper is represented by abbreviation (RO-IP) and mineral oil paper is represented by abbreviation (MI-IP).

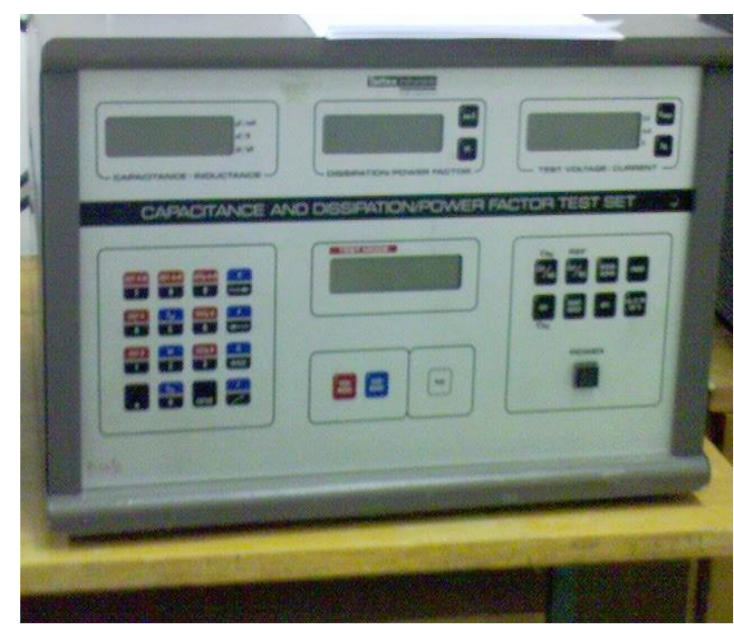

Fig. 2 Automatic Schering bridge

\subsection{Measurement of resistance}

Measurement of resistance belongs between the oldest and the simplest diagnostic method. Measurement of resistance after connection of DC voltage during the certain time interval is the principle of this method. Polarization index is used for assessment of quality of insulation system. It is ratio of resistance in two different time intervals. 1 minute polarization index and 10 minute polarization index are used in diagnostic of insulation system of electrical devices. It is ratio of resistances in 60 and 15 seconds after the connection voltage and resistance in 600 and 60 seconds. In this paper is used only 1 minute polarization index [7]. Unilap ISO $5 \mathrm{kV}$ was used for measurement of resistance (Fig.3). There was used the same electrode system, as with the measurement of dissipation factor and relative permittivity. Electrode system with sample is shown on (Fig. 4).

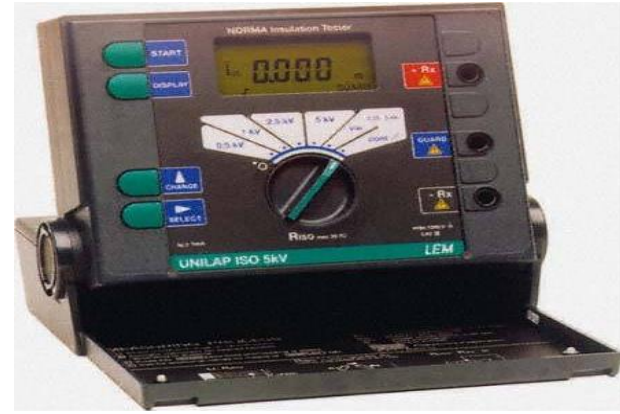

Fig. 3 Unilap ISO 5kV.

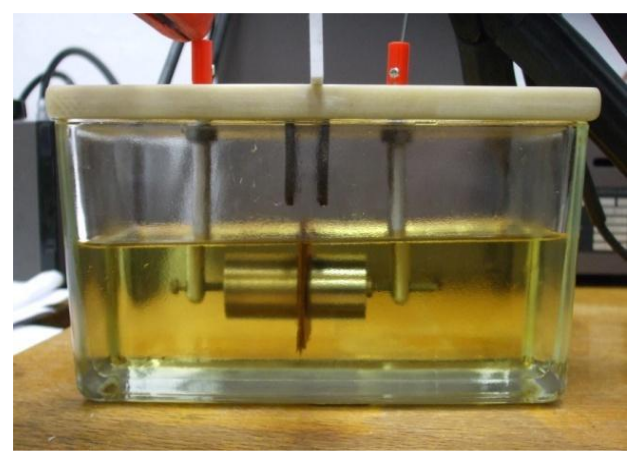

Fig. 4 Specimen of oil-paper insulation

\section{RESULTS AND DISCUSION}

Influence of thermal ageing on the breakdown voltage of different types of oil paper insulation is shown in Tab. 1 and Tab. 2

Table 1 Influence of thermal ageing on breakdown voltage of insulation paper impregnated by rapeseed oil

\begin{tabular}{|c|c|c|c|}
\hline \multirow{2}{*}{$\begin{array}{c}\text { number of } \\
\text { measuremt }\end{array}$} & RO-IP $0 \mathrm{~h} 0^{\circ} \mathrm{C}$ & RO-IP $500 \mathrm{~h} 90^{\circ} \mathrm{C}$ & RO-IP $750 \mathrm{~h} 90^{\circ} \mathrm{C}$ \\
\cline { 2 - 4 } & $\mathrm{Ub}(\mathrm{kV})$ & $\mathrm{Ub}(\mathrm{kV})$ & $\mathrm{Ub}(\mathrm{kV})$ \\
\hline 1 & 17.8 & 23.3 & 22.4 \\
\hline 2 & 18 & 20.7 & 24.8 \\
\hline 3 & 20.4 & 19.5 & 22.8 \\
\hline 4 & 19.2 & 20.7 & 23.4 \\
\hline 5 & 21.1 & 20.2 & 23.3 \\
\hline Average & 19.3 & 20.88 & 23.34 \\
\hline
\end{tabular}

Electrical discharge is statistically random phenomenon, therefore measurement of breakdown voltage was realized five times. Then average value was calculated. Table of breakdown voltage of rapeseed oil paper show that breakdown voltage is higher than breakdown voltage of mineral oil paper. This fact is confirmed also the average values of breakdown voltage. Average value of breakdown voltage before thermal ageing for rapeseed oil paper is $19.3 \mathrm{kV}$ while for mineral oil paper is $18.2 \mathrm{kV}$. For 500 hour thermal degradation at $90^{\circ} \mathrm{C}$ is this value $20.88 \mathrm{kV}$ for rapeseed oil paper and 
$20.3 \mathrm{kV}$ for mineral oil paper. The biggest difference is at 750 hour thermal ageing at $90^{\circ} \mathrm{C}$. Average value for this case is $23.34 \mathrm{kV}$ for rapeseed oil paper and $20.32 \mathrm{kV}$ for mineral oil paper. This fact is caused by evaporation of moisture from the oil and paper after thermal ageing.

Table 2 Influence of thermal ageing on breakdown voltage of insulation paper impregnated by mineral oil

\begin{tabular}{|c|c|c|c|}
\hline \multirow{2}{*}{$\begin{array}{c}\text { number of } \\
\text { measuremet }\end{array}$} & $\mathrm{MI}-\mathrm{IP} 0 \mathrm{~h} 0^{\circ} \mathrm{C}$ & $\mathrm{MI}-\mathrm{IP} 500 \mathrm{~h} 90^{\circ} \mathrm{C}$ & $\mathrm{MI}-\mathrm{IP} 750 \mathrm{~h} 90^{\circ} \mathrm{C}$ \\
\cline { 2 - 4 } & $\mathrm{Ub}(\mathrm{kV})$ & $\mathrm{Ub}(\mathrm{kV})$ & $\mathrm{Ub}(\mathrm{kV})$ \\
\hline 1 & 18 & 20.7 & 19.4 \\
\hline 2 & 18 & 20.3 & 20.1 \\
\hline 3 & 18.9 & 19.9 & 20.4 \\
\hline 4 & 17.9 & 19.3 & 20.6 \\
\hline 5 & 18.2 & 21.3 & 21.1 \\
\hline Average & $\mathbf{1 8 . 2}$ & $\mathbf{2 0 . 3}$ & $\mathbf{2 0 . 3 2}$ \\
\hline
\end{tabular}

Results from measuring of relative permittivity of rapeseed oil paper and mineral oil paper are shown at Fig. 5 and Fig 6. The samples were exposed thermal stress 0 hours, 500 hours at $90^{\circ} \mathrm{C}$ and 750 hours at $90^{\circ} \mathrm{C}$.

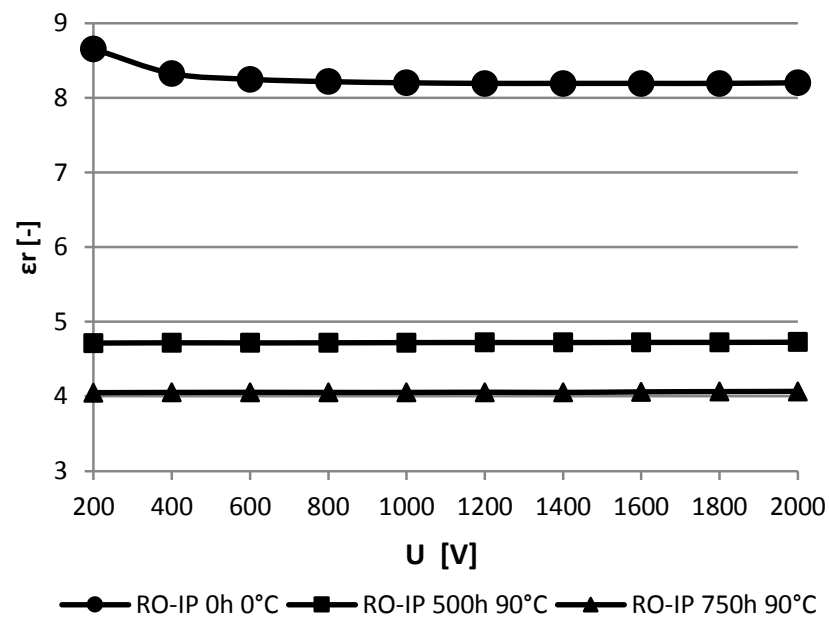

Fig. 5 Influence of thermal ageing on relative permittivity of insulation paper impregnated by rapeseed oil.

Temperature is one of the important factors influencing relative permittivity of insulating materials. The value of relative permittivity is decreasing after each thermal stresses. Natural esters absorbed three times more moisture as mineral oils. Decreasing of relative permittivity is caused by evaporation of moisture from oil paper. Relative permittivity of rapeseed oil paper before thermal ageing is 8.2 and after thermal ageing is 4.7 and 4.1 respectively.

Mineral oil paper insulation has lower value of relative permittivity as natural oil paper, generally. There are several differences against the natural oil paper insulation. First difference is that relative permittivity of mineral oil paper is increasing if voltage is increased in each of cases. The second difference is that, after first thermal ageing the value of relative permittivity is higher than before thermal ageing. The value of relative permittivity of mineral oil paper before thermal stresses was from 3.17 to 3.24 and after 750 hour thermal stresses was approximately 3 .

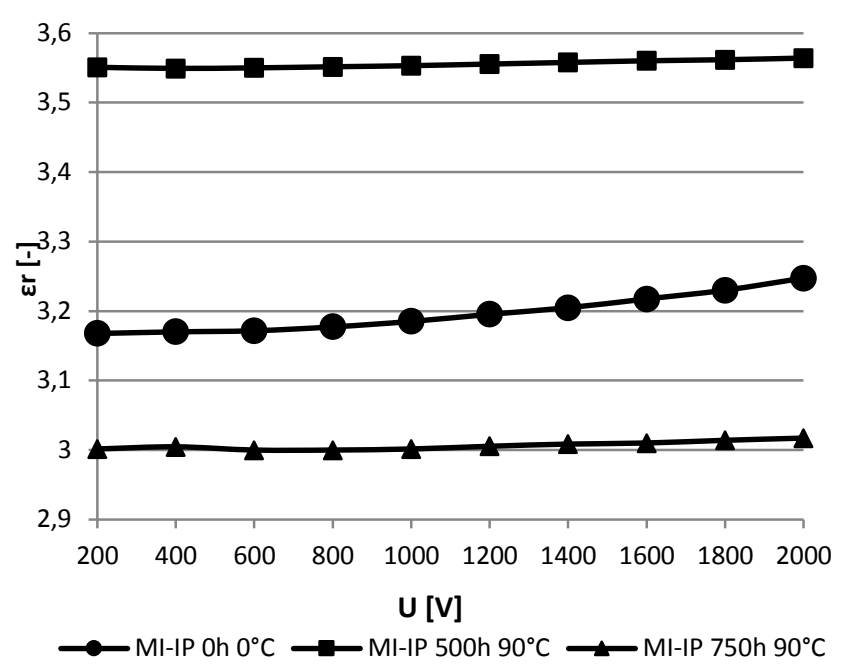

Fig. 6 Influence of thermal ageing on relative permittivity of insulation paper impregnated by mineral oil.

Results from measurement of resistance are in Tab. 3 and Tab.4. The resistance of mineral oil paper insulation is higher than resistance of rapeseed oil paper insulation. Thermal stress has a strong influence on the resistance and polarization index of oil paper insulation. The values of polarization index are increased after each thermal stress for both insulation systems. This fact has connection with moisture which is evaporated after thermal stress. That means the current which flowing through of insulation after connection DC voltage is lower.

Table 3 Polarization index of rapeseed oil paper insulation

\begin{tabular}{|c|c|c|c|c|c|}
\hline \multicolumn{2}{|c|}{ RO-IP Oh $\mathbf{0}^{\circ} \mathbf{C}$} & \multicolumn{2}{c|}{ RO-IP $500 \mathrm{~h} \mathbf{9 0}^{\circ} \mathbf{C}$} & \multicolumn{2}{c|}{ RO-IP 750h 90 ${ }^{\circ} \mathbf{C}$} \\
\hline $\mathbf{R}_{\mathbf{1 5}}$ & $\mathbf{R}_{\mathbf{6 0}}$ & $\mathbf{R}_{\mathbf{1 5}}$ & $\mathbf{R}_{\mathbf{6 0}}$ & $\mathbf{R}_{\mathbf{1 5}}$ & $\mathbf{R}_{\mathbf{6 0}}$ \\
\hline $1.021 \mathrm{G} \Omega$ & $1.026 \mathrm{G} \Omega$ & $72 \mathrm{G} \Omega$ & $90 \mathrm{G} \Omega$ & $320 \mathrm{G} \Omega$ & $440 \mathrm{G} \Omega$ \\
\hline \multicolumn{2}{|c|}{$\mathbf{p}_{\mathrm{i} 1}=1.005$} & \multicolumn{2}{|c|}{$\mathbf{p}_{\mathrm{i} 1}=1.25$} & \multicolumn{2}{c}{$\mathbf{p}_{\mathrm{i} 1}=1.37$} \\
\hline
\end{tabular}

Table 4 Polarization index of mineral oil paper insulation

\begin{tabular}{|c|c|c|c|c|c|}
\hline \multicolumn{2}{|c|}{$\mathrm{MI}-\mathrm{IP}$ Oh $0^{\circ} \mathrm{C}$} & \multicolumn{2}{|c|}{ MI-IP $500 \mathrm{~h} 90^{\circ} \mathrm{C}$} & \multicolumn{2}{|c|}{ MI-IP $750 \mathrm{~h} 90^{\circ} \mathrm{C}$} \\
\hline $\mathbf{R}_{\mathbf{1 5}}$ & $\mathbf{R}_{60}$ & $\mathbf{R}_{\mathbf{1 5}}$ & $\mathbf{R}_{60}$ & $\mathbf{R}_{\mathbf{1 5}}$ & $\mathbf{R}_{60}$ \\
\hline $44 \mathrm{G} \Omega$ & $45 \mathrm{G} \Omega$ & $96 \mathrm{G} \Omega$ & $1.16 \mathrm{~T} \Omega$ & $1.47 \mathrm{~T} \Omega$ & $1.93 \mathrm{~T} \Omega$ \\
\hline \multicolumn{2}{|c|}{$p_{i 1}=1.02$} & \multicolumn{2}{|c|}{$p_{i 1}=1.21$} & \multicolumn{2}{|c|}{$p_{i 1}=1.31$} \\
\hline
\end{tabular}

\section{CONCLUSIONS}

This paper provides view on the influence of thermal stress on the oil paper insulation. Mineral oil paper insulation and natural oil paper insulation were measured and analyzed. Breakdown voltage, relative permittivity and polarization index were measured. Measurement of dissipation factor wasn't the aim of this paper. There were used two different samples of oil paper insulation and two 
different thermal aging intervals. From the results we can make following conclusions.

* Tables of breakdown voltage show that breakdown voltage of rapeseed oil paper is higher than breakdown voltage of mineral oil paper.

* The value of relative permittivity is decreasing after each thermal stresses. Decreasing of relative permittivity is caused by evaporation of moisture from oil paper. Relative permittivity of mineral oil paper is increasing if voltage is increased in each of cases.

* The resistance of mineral oil paper insulation is higher than resistance of rapeseed oil paper insulation. Thermal stress has a strong influence on the resistance and polarization index of oil paper insulation.

\section{ACKNOWLEDGMENTS}

"We support research activities in Slovakia/This project is being co-financed by the European Union".Paper is the result of the Project implementation: University Science Park TECHNICOM for Innovation Applications Supported by Knowledge Technology, ITMS: 26220220182, supported by the Research \& Development Operational Programme funded by the ERDF."

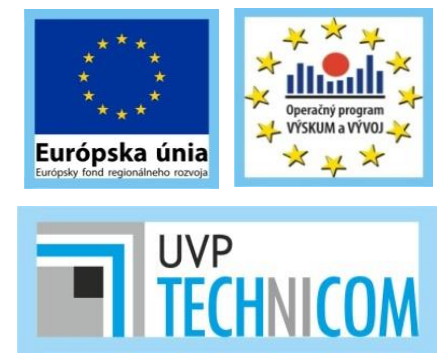

\section{REFERENCES}

[1] DRAWIN, A. - PERRIER, CH. - FOLLIOT, P.: The use of natural ester fluids in transformers. Mat Post 07:

online:www.matpost.org/...MATPOST07_0036_pap er.pdf.

[2] DAI, J. - WANG, D. Z:: A Comparison of the Impregnation of Cellulose Insulationby Ester and Mineral oil. IEEE Transactions on Dielectrics and Electrical Insulation Vol.15, No. 2; April 2008.ISBN 1070-9878/08.

[3] TANG, CH. et-al: Research on the dielectric properties and breakdown voltage of transformer oilpaper insulation after accelerating thermal ageing. High Voltage Engineering and Application (ICHVE), 2010 International Conference on New Orleans.11-14 Oct. 2010.ISBN 978-1-4244-8283-2.

[4] SHIM, M. S.: Comparative evaluation of aging of insulating, material in natural ester and mineral oil. High Voltage Engineering and Application
(ICHVE), 2010 International Conference on New Orleans.11-14 Oct. 2010.ISBN 978-1-4244-8283-2.

[5] LISOŇ, L. et-al: Research of electrophysical properties of oil-paper insulation: Electric Power Engineering (EPE), Proccedings of the 2014 15th International Scientific Conference on Brno. 12-14 May 2014.ISBN 978 - 1 - 4799 - 3806 - 3.

[6] DEDINSKÁ, L. - KOLCUNOVÁ, I.: Elektrické vlastnosti prírodných esterov. Publikácie TUKE Starnutie elektroizolačných systémov, č. 9 (2010) ISSN 1337-0103.

[7] KOLCUNOVÁ, I. - KURIMSKÝ, J. - DOLNÍK, B. - MATVIJA, M.: Diagnostika distribučného transformátora $\mathrm{V}$ laboratórnych podmienkach. Starnutie elektroizolačných systémov, č. 1 (2012) ISSN: 1337-0103.

Received November 25, 2014, accepted February 2, 2015

\section{BIOGRAPHIES}

Lukáš Lisoň is a Ph.D. student in the Department of Electric Power Engineering on the Faculty of Electrical Engineering and Informatics at Technical University in Košice. He received a master degree in electric power engineering on subject thermal degradation of insulation oils. His scientific research is mainly focused on research of electrophysical properties of paper insulation impregnated by natural esters.

Iraida Kolcunová was born in Kotlas, Russia, in 1955. She graduated from the Department of High Voltage Engineering, the Faculty of Power Engineering at the Moscow Power Engineering Institute in 1979. She received the $\mathrm{PhD}$ degree from Slovak Technical University in Bratislava in 1993. She became a Professor of Electric Power Engineering at the Faculty of Electrical Engineering and Informatics at the Technical University of Kosice in 2009. Since 1979 she has been working at the Technical University, first as a research worker in High Voltage Laboratory, then as a teacher at the Department of High Voltage Engineering. She deals with degradation of insulating materials and measuring of partial discharges in high voltage equipment. She is lecturing on Diagnostics of High Voltage Equipments and High Voltage Engineering.

Miroslav Kmec was born in 1988 in Bardejov, Slovakia. He received the B.E. and M.E. degrees in electrical power engineering from Technical University, Košice in 2010 and 2012 respectively. Today he is continuing his studies as a PhD student at the Department of Electrical Power Engineering, at the Technical University in Košice. His areas of interest are digital protective relays, power system Protection and adaptive relay setting for flexible AC transmission systems (FACTS). 